\title{
Article \\ Effects of least cost homemade ration on growth performance of Sasso and Indigenous breeds of chicks
}

\author{
Lemma Gulilat ${ }^{1,2, *}$, FirewTegegne ${ }^{1}$ and Solomon Demeke ${ }^{3}$ \\ 1 Animal production and technology, Bahir Dar University, Amhara, \\ Ethiopia; firewtegegne@yahoo.uk.co \\ 2 Anima Science Department, Debre Tabor University, Amhara, Ethiopia; \\ lemmagulilat2009@gmail.com \\ 3 Animal Science Department, Jimma University, Oromia, Ethiopia; \\ solomondemeke2000@gmail.com \\ * Correspondence: lemmagulilat2009@gmail.com,+251-910557693
}

Simple Summary: The effect of least cost homemade diet on Sasso T-44 line and Indigenous local ecotypes chicken growth performance was not studied in Ethiopia. The limitation of feed is the main challenge for chicken production for developing countries due to food computation with human being and high cost. Therefore, determining the level of commercial chicken diet by substituting least cost homemade diet is very important for developing counties like Ethiopia. The information also will contribute to a lot for the scientific literature in the area of chicken production and productivity. There are different studies on chicken growth performance in Ethiopia by using different types of feeds on different types of breeds in village, small scale and commercial production systems. However, the Sasso T-44 line breed was introduced in Ethiopia recently from French "Label Rouge" poultry producer as dual purpose (egg and meat) the growth performance, feed intake, adaptability and acceptability by the users was not well studied. Commercial feed is not accessible for the farmers' and small scale chicken producer that far apart from the capital city of Addis Ababa and substituting of this costly and limited amount of feed by least cost feed was untouched issue in the study area. Therefore, the objective of this study was to evaluate least cost ration on chicken growth performances and its economic feasibility. The results obtained indicated that increased levels of substitution of a commercial diet with a homemade diet significantly depressed $(p<0.001)$ mean daily feed consumption and retention of dry matter, nitrogen, and metabolizable energy. Growth rate as measured by mean daily weight gain, mean final body weight, and total feed consumption and feed cost were significantly miserable $(p<0.001)$ in an increased homemade diet.

\begin{abstract}
The objective of this study was to develop the least-cost starter's diet and evaluated its effect on the growth performance of Sasso breeds and Indigenous ecotype of chicks under the local condition of the South Gondar Zone. The effects of substitution of different levels of commercial starters ration with homemade diet on the growth performance of Sasso and Indigenous chicks were studied in Hiruy Abaregay village of Farta district. The research area is $586 \mathrm{~km}$ distant from the capital city of Addis Ababa, Ethiopia. A total of 510 Sasso T-44 and 90 Indigenous local ecotypes day-old chicks were randomly divided into five groups, each with 102 and 18 chicks, respectively. These were assigned into five treatments in which 100 (T1), 75 (T2), 50 (T3), 25 (T4), and 0\% (T5) of commercial starter's diet in factorial completely randomized design (CRD) with 3 replications for 60 days feeding period. The results obtained indicated that increased levels of substitution of a commercial diet with a homemade diet significantly depressed $(p<0.001)$ mean daily feed consumption and retention of dry matter, nitrogen, and metabolizable energy. Growth rate as measured by mean daily weight gain, mean final body weight, and total feed consumption and feed cost were significantly miserable $(p<0.001)$ in an increased homemade diet. On the contrary, there was an increase in feed conversion ratio and fiber content in high-level dilution of starter's commercial diet with a homemade diet. However, the groups of chicks on 0,25 , and $50 \%$ commercial
\end{abstract}


starters diets replaced by homemade diet were significantly higher $(p<0.001)$ in mean daily feed intake, daily weight gain, feed conversion ratio, and final body weight attained. The results of this study indicated that up to $50 \%$ of expensive commercial starter's diet could economically be replaced with the least cost homemade diet without adversely affecting the growth performance of chicks.

Keywords: Breed; Diet; Growth; Indigenous; Intake; Sasso

\section{Introduction}

In Ethiopia chicken plays a significant socio-economic role in the delivery of human food, family income, and the religious/cultural ceremonies of the society [1]. Indigenous chicken-based village poultry production has provided a major income-generating activity from the sale of live birds and eggs in smallholders of the societies. Eggs can provide a regular, albeit small, income while the sale of live birds provides a more flexible source of cash as required. Village poultry production is a source of self-reliance for women since the sale of live birds and eggs are decided by women [2], both of which provide women with an immediate income to meet household expenses such as food and cloth. The relatively modern Ethiopian poultry sub-sector comprises of small scale intensive poultry production system with modest flock sizes ranging from 50 to 1000 exotic breeds, operating on a more commercial basis. Small scale modern poultry supplies eggs and meat to the urban and peri-urban population [3]. Currently, the Ethiopian government, FAO (Food and Agricultural Organization of the United Nation), several Donor \& NGO (None Governmental organization) funded projects are involved in the implementation of poultry development plans in support of vulnerable households and jobless youths. Unfortunately, the major bottleneck of both the village and small modern poultry sub-sector is poor quality and high cost of feed [4].

There is unintended feeding of chickens under the backyard village production system in Ethiopia and scavenging is almost the only source of diet. The scavenging feed resource base is various depending on the season and insufficient for chicken production and productivity improvement due to its poor quality content. $[5,6]$. The processed chicken feed consisting mainly of cereal grains, cereal grain by-products, and oilseed cakes are obtainable from feed mills that are largely concentrated in and around the capital city of Ethiopia, Addis Ababa, which is far from the research area [6]. In addition to this, the price of raw materials to formulate commercial ration is fluctuates, the transport costs and lack of regional feed mills is the main challenge for smallholder chicken production and productivity in a rural area. These being the case, there is a strong need for the setup of the input supply system and feed packages and the development of least-cost regional poultry rations with the use of locally available feed resources seems to be appealing. Therefore, the objective of this study was;

1. To develop the least-cost starter's diet from locally available ingredients for Sasso breed and Indigenous ecotypes

2. To evaluate the effect of least cost starter's diet on growth performance of Sasso breed and Indigenous chicks

3. To assess the economic feasibility of the diets for village chicken production from local ingredients uses 


\section{Materials and Methods}

\subsection{Description of the area}

This research was conducted in South Gondar Administrative Zone, Farta district, and Hiruy Abaregay village. The research site is found in Amhara National Regional State at $586 \mathrm{~km}$ North West of Addis Ababa. The study area is located at an altitude of 2650 meters above sea level and lies between $11^{\circ} 32^{\prime}$ and $12^{\circ} 03^{\prime} \mathrm{N}$ latitude and $37^{\circ} 31^{\prime}$ and $38^{\circ} 43^{\prime} \mathrm{E}$ longitude. The mean annual rainfall is $1570 \mathrm{~mm}$ and the range of annual temperature is 9.6 and $21.5^{\circ} \mathrm{C}$ minimum and maximum, respectively.

\subsection{Management of the experimental chicken}

The experimental procedure was reviewed and approved by Debre Tabor University Research Ethics Committee (Ref. No. DTU10/20) and it was conducted by qualified and experienced personnel under the supervision of a veterinarian, according to the guidelines of the World Organization for Animal Health. A total of 510 Sasso T-44 breed day old chicks (DOCs) were purchased from Andasa Ethio-chicken poultry P.L.C farm and 90 Indigenous local ecotypes day old chicks were hatched with the use of thoroughly selected broody hen in the research area. Fifteen (15) broody hens with the same age and body size $(960 \pm 40 \mathrm{~g})$ were purchased from the local market. Then, was divided randomly into three groups that consist of 5 broody hens for each incubated 10 fertile eggs. Before incubation, all broody hens will be treated to remove both internal and external parasites and offered complete ration containing $12.9 \mathrm{MJ} / \mathrm{kg}$ and $16.4 \%$ $\mathrm{CP}$ and fresh drinking water as Ad libitum feeding system.

All-day-old chicks were weighed, vaccinated, and divided into five groups each with 102 Sasso and 18 Indigenous chicks. All the groups of chicks were transported and randomly offered to a selected and well trained household participants who have well cleaned, disinfected, and prepared hay box brooders. The hay box brooder was constructed from locally available materials such as; bamboo, teff straw, wood, and mish wire based on the space requirement of Sasso breed and Indigenous ecotypes. Chicks were vaccinated against Newcastle Diseases, Gumboro, and Marek's diseases on standard schedules. Finally, the chicks were assigned to 5 dietary treatments with 3 replications as shown in Table 1 in factorial completely randomized design (CRD). The feed consumption for the chicken was measured daily whereas body weights were taken weekly.

Table 1 Treatment Allocation to the Experimental Chicks

\begin{tabular}{|l|l|l|l|l|l|}
\hline Treatments & $\begin{array}{l}\text { Sasso } \\
\text { Chicks/Tr. }\end{array}$ & $\begin{array}{l}\text { Indigenous } \\
\text { chicks/Tr. }\end{array}$ & Rep/Tr. & $\begin{array}{l}\text { Sasso/ } \\
\text { Rep }\end{array}$ & $\begin{array}{l}\text { Indigenou } \\
\text { s /rep }\end{array}$ \\
\hline $\begin{array}{l}100 \% \text { Commercial starter's diet plus } \\
0 \% \text { homemade starters diet (T1) }\end{array}$ & 102 & 18 & 3 & 34 & 6 \\
\hline $\begin{array}{l}75 \% \text { Commercial starter's diet plus } \\
25 \% \text { homemade starters diet (T2) }\end{array}$ & 102 & 18 & 3 & 34 & 6 \\
\hline $\begin{array}{l}50 \% \text { Commercial starter's diet plus } \\
50 \% \text { homemade starters diet (T3) }\end{array}$ & 102 & 18 & 3 & 34 & 6 \\
\hline
\end{tabular}




\begin{tabular}{|l|l|l|l|l|l|}
\hline $\begin{array}{l}25 \% \text { Commercial starter's diet plus } \\
75 \% \text { homemade starters diet (T4) }\end{array}$ & 102 & 18 & 3 & 34 & 6 \\
\hline $\begin{array}{l}0 \% \text { Commercial starter's diet plus } \\
100 \% \text { homemade starters diet (T5) }\end{array}$ & 102 & 18 & 3 & 34 & 6 \\
\hline
\end{tabular}

\subsection{Composition and preparation of a least-cost diet}

The least-cost homemade diet was formulated by using locally available feed ingredients such as maize, wheat bran, sorghum, millet, barley, noug seed cake, and wheat were purchased from the local market and transported to the study area. Commercial starter's diet were used as a positive control, and purchased from Andasa Ethio-chicken poultry farm and transported to the study site. For feed chemical analysis, representative samples of the feed ingredients, formulated diet and commercial diet were collected, and pass through $1 \mathrm{~mm}$ sieves and stored in airtight bags until required for laboratory analysis. The dry matter (DM), Crude protein (CP), ether extract (EE), crude fat (CF), crude fiber $(\mathrm{CF})$, and total ash were determined according to [7]. The metabolizable energy (ME) content of the feed ingredients and commercial starter's diet were estimated using regression and summation equations $[8,9]$.

Finally, based on the result of the laboratory analytical data least cost homemade starter's diet were formulated based on the nutrient requirement of Sasso breed and indigenous ecotypes of chickens which contained $2955 \mathrm{kcal} / \mathrm{kg}$ of energy and $19.39 \%$ proteins, using winfeed 2.8 software as indicated in Table 2.

Table 2 Composition of ingredients in the experimental diet

\begin{tabular}{|c|c|c|c|c|c|}
\hline \multirow{2}{*}{ Ingredients } & \multicolumn{5}{|c|}{ Ingredients composition/proportion/ } \\
\cline { 2 - 6 } & $\mathrm{T} 1$ & $\mathrm{~T} 2$ & $\mathrm{~T} 3$ & $\mathrm{~T} 4$ & $\mathrm{~T} 5$ \\
\hline Maize & 0 & 8.2 & 16.4 & 24.6 & 32.8 \\
\hline Wheat bran & 0 & 6.1 & 12.2 & 18.3 & 24.4 \\
\hline Noug seed cake & 0 & 5.8 & 11.6 & 17.4 & 23.2 \\
\hline Wheat grain & 0 & 2.2 & 4.4 & 6.6 & 8.8 \\
\hline Sorghum grain & 0 & 1.2 & 2.4 & 3.6 & 4.8 \\
\hline Millet grain & 0 & 1.2 & 2.4 & 3.6 & 4.8 \\
\hline Barley grain & 0 & 0.3 & 0.6 & 0.9 & 1.2 \\
\hline Commercial feed & 100 & 75 & 50 & 25 & 0 \\
\hline
\end{tabular}

$\mathrm{T} 1=0 \%$ least cost diet; $\mathrm{T} 2=25 \%$ least-cost diet; $\mathrm{T} 3=50 \%$ least-cost diet; $\mathrm{T} 4=75 \%$ least-cost diet and $\mathrm{T} 5=100 \%$ least cost diet

\subsection{Data collection}

The experimental feeding trial lasted for about 8 and 24 weeks for Sasso and Indigenous chicks, respectively. Data for feed intake, daily weight gain, final weight gain were collected. The partial budget analysis was done according to 
[10] to determine the comparative economic feasibility of the commercial and homemade starters' diet were studied. Chicken and feed cost and the profit after the experiment were considered into, or differences between gains and losses for the proposed change. The net income (NI) was calculated by subtracting total variable cost (TVC) from the total return equation 1.

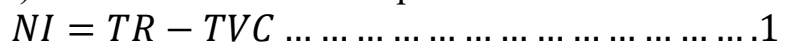

The change in net income $(\Delta \mathrm{NI})$ expressed as the difference between the change in total return $(\triangle \mathrm{TR})$ and total variable cost $(\triangle \mathrm{TVC})$ mathematically represented as;

$$
\Delta N I=\Delta T R-\Delta T V C
$$

The marginal rate of return (MRR) measures the increase in net income $(\Delta \mathrm{NI})$ related to each additional unit of expenditure $(\triangle \mathrm{TVC})$ and expressed in the percentage (equation 3).

$$
\% M R R=\frac{\Delta N I}{\Delta T V C} * 100 \ldots \ldots \ldots \ldots \ldots \ldots \ldots \ldots \ldots
$$

\subsection{Statistical analysis methods}

All the data collected were subjected to statistical analysis of variance using the PROC GLM of Statistically Analysis software SAS 9.2 version [11]. Least Significant Difference (LSD) procedure were used. The following model was used to test the growth performance of the chicken that affected by types of breed, types of diet and their interaction.

Where;

$$
Y_{i j}=\mu+B_{i}+R+B R_{i j}+\varepsilon_{i j \ldots \ldots \ldots \ldots \ldots \ldots \ldots . . .4}
$$

$\mathrm{Y}_{i j}=$ the $i^{\text {th }}$ observation of $i^{\text {th }}$ breed (B), the $j^{\text {th }}$ ration (R),

$\mu=$ is the general mean

$\mathrm{B}_{i}=$ the effect of level $i$ of factor breed (B)

$\mathrm{R}_{j}=$ the effect of level $j$ of factor ration $(\mathrm{R})$

$(\mathrm{BR})_{i j}=$ the effect of level $i j$ of factor interaction between breed and ration, $\varepsilon_{i j}=$ is the random error associated with $\mathrm{Y}_{i j}$ observation. (Mean was separated by using LCD)

\section{Results}

\subsection{Chemical analysis of the experimental diet}

The proximate composition and metabolizable contents of this diet are presented in Table 3. The dry matter ranges from $92 \%$ (T5) to $94.2 \%$ (T1), crude protein $18 \%$ (T5) to $20.9 \%$ (T1), crude fiber $4 \%$ (T1) to $10 \%$ (T5), EE is ranged $3 \%$ (T1) to $6 \%$ (T5) and energy 2875 (T5) to 3035 (T1) kcal ME/kg. The least-cost diet under this experiment had low crude protein and metabolizable energy but higher fiber content as compared to a commercial diet.

Table 3 Chemical analysis of the experimental diets

\begin{tabular}{|c|c|c|c|c|c|}
\hline \multicolumn{7}{|c|}{ Chemical analysis of the diet } \\
\hline Nutrients & T1 & T2 & T3 & T4 & T5 \\
\hline DM \% & 94.2 & 94 & 93.6 & 92 & 91 \\
\hline CP\% DM bases & 20.9 & 20.3 & 19 & 18.7 & 18 \\
\hline CF\% DM bases & 4 & 4.5 & 6.4 & 8.5 & 10 \\
\hline EE\% DM bases & 3 & 3.8 & 5.4 & 5.8 & 6 \\
\hline ME kcal/kg & 3035 & 3000 & 2975 & 2890 & 2875 \\
\hline
\end{tabular}

$\mathrm{T} 1=0 \%$ least-cost diet; $\mathrm{T} 2=25 \%$ least-cost diet; $\mathrm{T} 3=50 \%$ least cost diet; $\mathrm{T} 4=75 \%$ least cost diet and $\mathrm{T} 5=100 \%$ least cost diet 


\subsection{Feed consumption}

The results of the mean feed consumption at different age of the experimental chicks are presented in table 4-6. During the first four weeks the mean daily feed consumption (MDFC) and mean weekly feed consumption (MWFC) of Indigenous chicken fed $0 \%$ commercial diet had significantly $(p<0.05)$ lower than Sasso breeds and Indigenous ecotypes on 25, 50, 75 and 100\% commercial diet. But mean total feed consumption (MTFC) during these four weeks, the Sasso birds had significantly $(p<0.001)$ higher than Indigenous ecotype. During the second four weeks (5-8 weeks), MDFC, MWFC, and MTFC were significant $(p<0.001)$ among the breeds. MDFC, MWFC, and MTFC during 9-24 weeks the Indigenous ecotype on $0 \%$ commercial had highly significant $(p<0.001)$ lower than birds on $25,50,75$, and $100 \%$ commercial diet. The clear effect of least-cost diet inclusion on nutrient composition was a progressive increase in crude fiber content from $4 \%$ at the $0 \%$ least-cost diet inclusion level to $10 \%$ at the $100 \%$ least-cost diet level (Table 3). Feed intake also decreased with increasing of leastcost diet level. 
Table 4 Mean feed consumption and growth performance of Sasso and Indigenous chicks during the first 4 weeks

\begin{tabular}{|c|c|c|c|c|c|c|c|c|c|c|c|}
\hline \multirow[t]{2}{*}{ Parameters } & \multicolumn{5}{|c|}{ Sasso T-44 } & \multicolumn{5}{|c|}{ Indigenous local ecotypes } & \multirow{2}{*}{$\begin{array}{l}p \text { - } \\
\text { value }\end{array}$} \\
\hline & T1 & $\mathrm{T} 2$ & T3 & $\mathrm{T} 4$ & T5 & $\mathrm{T} 1$ & $\mathrm{~T} 2$ & $\mathrm{~T} 3$ & $\mathrm{~T} 4$ & T5 & \\
\hline MDFC at $1^{\text {st }} 4$ weeks $g /$ head & $20.4^{\mathrm{a}}$ & $19.7^{\mathrm{a}}$ & $21.0^{\mathrm{a}}$ & $29.1^{\mathrm{a}}$ & $22.7^{\mathrm{a}}$ & $10.3^{\mathrm{a}}$ & $8.6^{\mathrm{a}}$ & $8.1^{\mathrm{a}}$ & $7.4^{\mathrm{a}}$ & $6.6^{\mathrm{b}}$ & 0.05 \\
\hline MWFC at $1^{\text {st }} 4$ week $g /$ head) & $143.4^{\mathrm{a}}$ & $138.1^{\mathrm{a}}$ & $147.6^{\mathrm{a}}$ & $204.1^{\mathrm{a}}$ & $158.9^{\mathrm{a}}$ & $72.3^{\mathrm{a}}$ & $60.2^{\mathrm{a}}$ & $56.7^{\mathrm{a}}$ & $52.4^{\mathrm{a}}$ & $46.8^{\mathrm{b}}$ & 0.05 \\
\hline MTFC at $1^{\text {st }} 4$ week $\left.\mathrm{g} / \mathrm{head}\right)$ & $17718.0^{\mathrm{a}}$ & $18937.1^{\mathrm{a}}$ & $19115.9^{\mathrm{a}}$ & $28607.2^{\mathrm{a}}$ & $21655.9^{\mathrm{a}}$ & $1440.5^{b}$ & $1549.5^{\mathrm{b}}$ & $1275.0^{\mathrm{b}}$ & $1322^{\mathrm{b}}$ & $1070.0^{\mathrm{b}}$ & $<0.001$ \\
\hline MIBW (g/head) & $56.5^{\mathrm{a}}$ & $53.3^{\mathrm{a}}$ & $48.8^{\mathrm{a}}$ & $56.8^{\mathrm{a}}$ & $50.0^{\mathrm{a}}$ & $26.2^{\mathrm{b}}$ & $26.6^{\mathrm{b}}$ & $24.3^{\mathrm{b}}$ & $25.5^{\mathrm{b}}$ & $25.8^{\mathrm{b}}$ & $<0.001$ \\
\hline $\begin{array}{l}\text { MFBW at end of } 1^{\text {st }} 4 \text { week } \\
\mathrm{g} / \mathrm{head} \text { ) }\end{array}$ & $228.5^{\mathrm{a}}$ & $232.6^{\mathrm{a}}$ & $172.6^{\mathrm{a}}$ & $181.1^{\mathrm{a}}$ & $108.1^{\mathrm{b}}$ & $51.5^{\mathrm{b}}$ & $51.7^{\mathrm{b}}$ & $52.5^{\mathrm{b}}$ & $55.1^{\mathrm{b}}$ & $51.4^{\mathrm{b}}$ & $<0.001$ \\
\hline MDBWG $1^{\text {st }} 4$ weeks g/head) & $3.9^{\mathrm{a}}$ & $4.1^{\mathrm{a}}$ & $3.3^{\mathrm{a}}$ & $3.3^{\mathrm{a}}$ & $2.4^{\mathrm{b}}$ & $1.2^{\mathrm{c}}$ & $1.2^{\mathrm{c}}$ & $1.2^{\mathrm{c}}$ & $1.5^{\mathrm{c}}$ & $1.2^{\mathrm{c}}$ & $<0.001$ \\
\hline MWBWG $1^{\text {st }} 4$ weeks (g/head) & $29.9^{\mathrm{a}}$ & $30.9^{\mathrm{a}}$ & $24.8^{\mathrm{a}}$ & $24.8^{\mathrm{a}}$ & $18.2^{\mathrm{b}}$ & $9.6^{\mathrm{c}}$ & $9.4^{\mathrm{c}}$ & $9.4^{\mathrm{c}}$ & $11.5^{\mathrm{c}}$ & $9.4^{\mathrm{c}}$ & $<0.001$ \\
\hline $\begin{array}{l}\text { MTBWG during the } 1^{\text {st }} 4 \text { weeks } \\
\text { g/head) }\end{array}$ & $3441.6^{\mathrm{a}}$ & $3964.8^{\mathrm{a}}$ & $2999.0^{\mathrm{a}}$ & $3291.4^{\mathrm{a}}$ & $2337.9^{b}$ & $184.4^{\mathrm{c}}$ & $227.8^{c}$ & $201.6^{c}$ & $272.0^{\mathrm{c}}$ & $203.7^{c}$ & $<0.001$ \\
\hline Mean FCR during at $1^{\text {st }} 4$ weeks & 1.2 & 1.2 & 1.5 & 2.9 & 2.0 & 2.8 & 3.0 & 3.0 & 3.0 & 3.0 & 0.65 \\
\hline
\end{tabular}

$\mathrm{MDFC}=$ mean daily feed consumption; MWFC=mean weekly feed consumption; MTFC=mean total feed consumption; MIBW=mean initial body

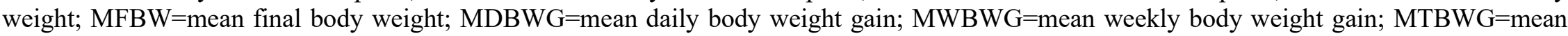
total body weight gain; $\mathrm{FCR}=$ feed conversion ratio; $\mathrm{T} 1=0 \%$ least-cost diet; $\mathrm{T} 2=25 \%$ least-cost diet; $\mathrm{T} 3=50 \%$ least-cost diet; $\mathrm{T} 4=75 \%$ least-cost diet and $\mathrm{T} 5=100 \%$ least-cost diet; Similar letters are indicated no significant difference

Table 5 Mean feed consumption and growth performance of Sasso and Indigenous chicks during 5-8 weeks

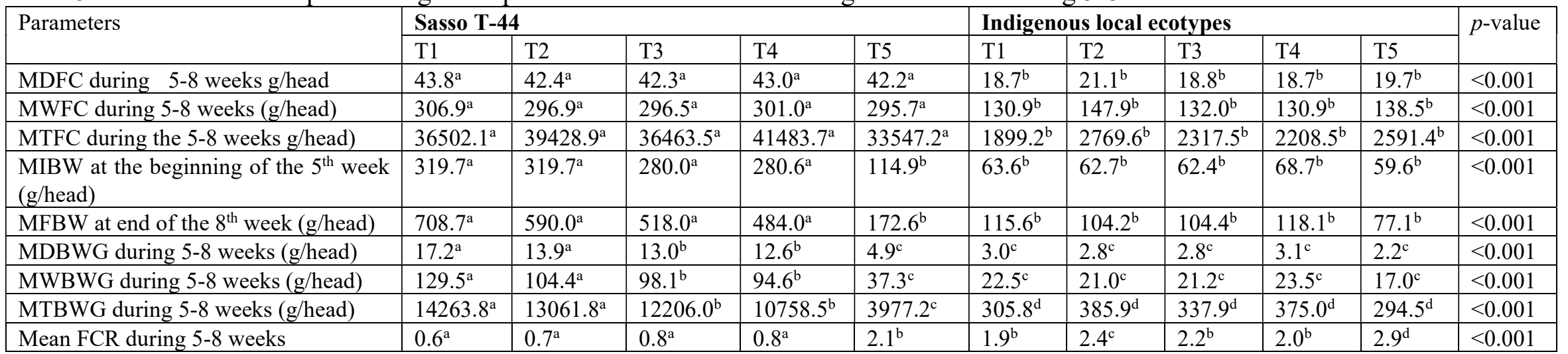

$\mathrm{MDFC}=$ mean daily feed consumption; MWFC=mean weekly feed consumption; $\mathrm{MTFC}=$ mean total feed consumption; MIBW=mean initial body

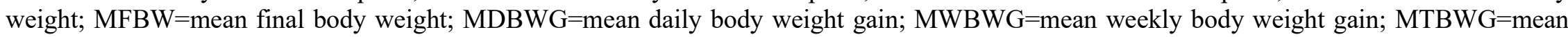
total body weight gain; $\mathrm{FCR}=$ feed conversion ratio; $\mathrm{T} 1=0 \%$ least-cost diet; $\mathrm{T} 2=25 \%$ least-cost diet; $\mathrm{T} 3=50 \%$ least-cost diet; $\mathrm{T} 4=75 \%$ least-cost diet and $\mathrm{T} 5=100 \%$ least-cost diet; Similar letters are indicated no significant difference 
Table 6 Mean feed consumption and growth performance of Indigenous chicks during 9-24 weeks

\begin{tabular}{|l|l|l|l|l|l|l|}
\hline \multirow{2}{*}{ Parameters } & \multicolumn{4}{l|}{ Indigenous ecotype } & \multirow{2}{l|}{ p-value } \\
\cline { 2 - 7 } & $\mathrm{T} 1$ & $\mathrm{~T} 2$ & $\mathrm{~T} 3$ & $\mathrm{~T} 4$ & $\mathrm{~T} 5$ & \\
\hline MDFC (9-24) weeks g/head & $50.1^{\mathrm{a}}$ & $41.9^{\mathrm{b}}$ & $38.4^{\mathrm{b}}$ & $41.8^{\mathrm{b}}$ & $33.9^{\mathrm{c}}$ & $<0.001$ \\
\hline MWFC (9-24) week (g/head) & $1403.4^{\mathrm{a}}$ & $1175.2^{\mathrm{b}}$ & $1075.8^{\mathrm{b}}$ & $1172.9^{\mathrm{b}}$ & $951.0^{\mathrm{c}}$ & $<0.001$ \\
\hline MTFC (9-24) weeks (g/head) & $18043.9^{\mathrm{a}}$ & $15110.0^{\mathrm{a}}$ & $14058.6^{\mathrm{b}}$ & $15080.8^{\mathrm{b}}$ & $12344.2^{\mathrm{c}}$ & $<0.001$ \\
\hline $\begin{array}{l}\text { MIBW at the beginning of the } 9^{\text {th }} \\
\text { week (g/head) }\end{array}$ & $131.3^{\mathrm{a}}$ & $115.1^{\mathrm{a}}$ & $116.1^{\mathrm{a}}$ & $128.4^{\mathrm{a}}$ & $87.1^{\mathrm{b}}$ & $<0.001$ \\
\hline $\begin{array}{l}\text { MFBW at the end of the 24 } \\
\text { week (g/head) }\end{array}$ & $733.6^{\mathrm{a}}$ & $635.3^{\mathrm{b}}$ & $595.0^{\mathrm{c}}$ & $525.3^{\mathrm{d}}$ & $446.5^{\mathrm{e}}$ & $<0.001$ \\
\hline MDBWG (9-24) weeks (g/head) & $3.3^{\mathrm{a}}$ & $2.5^{\mathrm{b}}$ & $2.5^{\mathrm{b}}$ & $2.4^{\mathrm{b}}$ & $1.9^{\mathrm{c}}$ & $<0.001$ \\
\hline $\begin{array}{l}\text { MWBWG (9-24) weeks } \\
\text { (g/head) }\end{array}$ & $24.8^{\mathrm{a}}$ & $19.3^{\mathrm{b}}$ & $19.2^{\mathrm{bc}}$ & $18.4^{\mathrm{c}}$ & $14.6^{\mathrm{d}}$ & $<0.001$ \\
\hline MTBWG (9-24)weeks (g/head) & $1191.3^{\mathrm{a}}$ & $928.3^{\mathrm{b}}$ & $928.6^{\mathrm{b}}$ & $885.4^{\mathrm{c}}$ & $709.0^{\mathrm{d}}$ & $<0.001$ \\
\hline Mean FCR during 9-24 weeks & $3.4^{\mathrm{c}}$ & $4.13^{\mathrm{b}}$ & $4.5^{\mathrm{b}}$ & $4.7^{\mathrm{b}}$ & $5.7^{\mathrm{a}}$ & $<0.001$ \\
\hline
\end{tabular}

$\mathrm{MDFC}=$ mean daily feed consumption; $\mathrm{MWFC}=$ mean weekly feed consumption; $\mathrm{MTFC}=$ mean total feed consumption; MIBW=mean initial body weight; MFBW=mean final body weight; $\mathrm{MDBWG}=$ mean daily body weight gain; $\mathrm{MWBWG}=$ mean weekly body weight gain; $\mathrm{MTBWG}=$ mean total body weight gain; $\mathrm{FCR}=$ feed conversion ratio; $\mathrm{T} 1=0 \%$ least-cost diet; $\mathrm{T} 2=25 \%$ least-cost diet; $\mathrm{T} 3=50 \%$ least-cost diet; $\mathrm{T} 4=75 \%$ least-cost diet and $\mathrm{T} 5=100 \%$ leastcost diet; Similar letters are indicated no significant difference

\subsection{Feed conversion ratio}

The results of the feed conversion ratio of the experimental chicks are presented in table 4-6. During the first four weeks, the mean feed conversion ratio (MFCR) were not significant $(\mathrm{P}>0.05)$ between the breeds. However, during the second four weeks (5-8 weeks) MFCR of Sasso breed on T1, T2, T3 and T4 commercial diet were showed significantly $(p<0.001)$ higher than Sasso breed on T5 commercial diet and Indigenous ecotype which fed all diets. The MFCR during 9-24 weeks of Indigenous ecotype fed 100\% commercial diet had significantly $(p<0.001)$ higher than birds fed $75,50,25$, and $0 \%$ commercial diet.

\subsection{Growth performance}

The results of the growth performance of the experimental chicks are presented in Table 4-6 and Figures 1 and 2. During the first four weeks, the mean daily body weight gain (MDBWG), mean weekly body weight gain (MWBWG), mean total body weight gain (MTBWG) and mean final body weight (MFBW) at the end of the fourth week were significantly $(p<0.001)$ lower in Sasso breed fed $0 \%$ commercial diet and Indigenous ecotype in all diets than birds on 25, 50, 75 and $100 \%$ commercial diet. However, the mean initial body weight (MIBW) at day old age was not significant $(p>0.05)$ in both Sasso breeds and indigenous ecotype. During the second four weeks (5-8 weeks), the MIBW at the beginning of week five Sasso breed fed $0 \%$ commercial diet were not significant $(p>0.05)$ between Indigenous ecotype fed 100, 75, 50, and 25\% commercial diet. Yet, the MDBWG, MWBWG, and MTBWG of Sasso breed fed 100 and $75 \%$ commercial diet had highly significant $(p<0.001)$ among the other treatments and Indigenous ecotype. The MIBW at the beginning of week nine, Indigenous chicken fed $0 \%$ commercial diet had significantly $(p<0.001)$ lower than birds on $25,50,75$, and $100 \%$ commercial diet. Nevertheless, MDBWG, MWBWG, MTBWG, and MFBW at the end of the $24^{\text {th }}$ week, Indigenous chicken fed $100 \%$ commercial diet had highly significant $(p<0.001)$ among the other treatments. 


\subsection{Economic feasibility of least-cost ration}

The results of the relative economic feasibility of using the least cost and commercial starter's diets in raising Sasso and Indigenous chicks are presented in Tables 7 and 8 . The purchasing price of commercial feed were higher than the price of the least-cost diet in the study area as presented in table 8 . But the price with the diets is not significantly $(p>0.05)$ different among the treatment but highly significant $(p<0.001)$ between breeds. Chicks on 0,25 and $50 \%$ least-cost diet had significantly $(p<0.001)$ high profitable as compared to chicks fed 75 and $100 \%$ least-cost diet in Sasso breed but not profitable for Indigenous chicken. This indicated that Indigenous ecotype under intensive production system was not profitable. This is may be due to used low number of indigenous birds for the experiment and high incidence of death occurred. Therefore, the inclusion of 75 and $100 \%$ of the least-cost diet is not profitable under this experiment due to the body weight gain of the chicken was low. There were significant differences $(p<0.001)$ among treatments in the cost of gross income, total return, and net return but no difference in chick's cost, feed cost, and total variable cost. Chicks fed 75 and $100 \%$ least-cost diet had significantly $(p<0.001)$ lower costs of net income than birds on a control diet. Commercial diet increased $(p<0.001)$ costs of feed at both breeds as compared to least-cost diet inclusion levels but had good body weight gain. The cost of daily feed intake and the cost of total feed intake decreased with increasing least-cost diet levels in both breeds. The observed increase in feed cost per kg weight gain may be attributed to an increase in ADFI but poor feed conversion efficiency and utilization, and poor growth rate of chicks that consumed diets containing high levels of least-cost diet. Nevertheless, a commercial diet significantly $(p<0.001)$ reduced feed cost per $\mathrm{kg}$ weight gain.

Table 7 Mean Economic feasibility of least cost diet for each treatment

\begin{tabular}{|l|l|l|l|l|l|l|l|}
\hline \multirow{2}{*}{ Parameters cost/Ethbr/ } & Treatments & \multirow{2}{*}{ Mean } & p-value \\
\cline { 2 - 8 } & $\mathrm{T} 1$ & $\mathrm{~T} 2$ & $\mathrm{~T} 3$ & $\mathrm{~T} 4$ & $\mathrm{~T} 5$ & & \\
\hline Chicks purchased cost & $1079^{\mathrm{a}}$ & $1079^{\mathrm{a}}$ & $1079^{\mathrm{a}}$ & $1079^{\mathrm{a}}$ & $1079^{\mathrm{a}}$ & 1079 & - \\
\hline Commercial feed cost & $758^{\mathrm{a}}$ & $638^{\mathrm{a}}$ & $390^{\mathrm{b}}$ & $220^{\mathrm{b}}$ & $0^{\mathrm{c}}$ & 401 & 0.001 \\
\hline Local feed cost & $0^{\mathrm{d}}$ & $156^{\mathrm{c}}$ & $287^{\mathrm{b}}$ & $486^{\mathrm{a}}$ & $534^{\mathrm{a}}$ & 293 & 0.001 \\
\hline Total feed cost & 758 & 795 & 678 & 706 & 534 & 694 & 0.1301 \\
\hline Total variable cost & 1837 & 1874 & 1757 & 1785 & 1614 & 1773 & 0.1301 \\
\hline Gross income & $3238^{\mathrm{a}}$ & $3516^{\mathrm{a}}$ & $2600^{\mathrm{ab}}$ & $2643^{\mathrm{ab}}$ & $1373^{\mathrm{b}}$ & 2674 & 0.0057 \\
\hline Total return & $2159^{\mathrm{a}}$ & $2437^{\mathrm{a}}$ & $1520^{\mathrm{ab}}$ & $1564^{\mathrm{ab}}$ & $294^{\mathrm{b}}$ & 1595 & 0.0057 \\
\hline Net return & $322^{\mathrm{a}}$ & $563^{\mathrm{a}}$ & $-237^{\mathrm{b}}$ & $-221^{\mathrm{b}}$ & $-1319^{\mathrm{c}}$ & -178 & 0.0027 \\
\hline
\end{tabular}

$\mathrm{T} 1=0 \%$ least-cost diet; $\mathrm{T} 2=25 \%$ least-cost diet; T3 $=50 \%$ least cost diet; T4 $=75 \%$ least cost diet and T5 $=100 \%$ least cost diet; Similar letters are indicated no significant difference 
Table 8 Economic feasibility of least cost diet for Sasso and Indigenous chicks in each treatments

\begin{tabular}{|c|c|c|c|c|c|c|c|c|c|c|c|c|}
\hline \multirow[t]{3}{*}{ Parameters cost/Ethbr/ } & \multicolumn{10}{|l|}{ Breeds } & \multirow[t]{3}{*}{ Mean } & \multirow[t]{3}{*}{$p$-value } \\
\hline & \multicolumn{5}{|c|}{ Sasso T-44 breed } & \multicolumn{5}{|c|}{ Indigenous ecotype } & & \\
\hline & T1 & $\mathrm{T} 2$ & T3 & $\mathrm{T} 4$ & T5 & $\mathrm{T} 1$ & $\mathrm{~T} 2$ & $\mathrm{~T} 3$ & T4 & T5 & & \\
\hline Chick's purchased cost & $929.0^{\mathrm{a}}$ & $929.0^{\mathrm{a}}$ & $929.0^{\mathrm{a}}$ & $929.0^{\mathrm{a}}$ & $929.0^{\mathrm{a}}$ & $150.0^{\mathrm{b}}$ & $150.0^{\mathrm{b}}$ & $150.0^{\mathrm{b}}$ & $150.0^{\mathrm{b}}$ & $150.0^{\mathrm{b}}$ & 539.5 & 0.001 \\
\hline Feed cost & $354.8^{\mathrm{a}}$ & $358.9^{\mathrm{a}}$ & $311.2^{\mathrm{a}}$ & $322.2^{\mathrm{a}}$ & $245.6^{\mathrm{a}}$ & $24.5^{\mathrm{b}}$ & $38.7^{\mathrm{b}}$ & $28.1^{\mathrm{b}}$ & $31.2^{\mathrm{b}}$ & $21.9^{\mathrm{b}}$ & 173.7 & 0.002 \\
\hline Total variable cost & $1283.8^{\mathrm{a}}$ & $1288.0^{\mathrm{a}}$ & $1240.2^{\mathrm{a}}$ & $1251.2^{\mathrm{a}}$ & $1174.5^{\mathrm{a}}$ & $174.5^{\mathrm{b}}$ & $188.6^{\mathrm{b}}$ & $178.1^{\mathrm{b}}$ & $181.2^{\mathrm{b}}$ & $171.9^{\mathrm{b}}$ & 713.2 & 0.001 \\
\hline Gross income cost & $3043.3^{\mathrm{a}}$ & $3336.6^{\mathrm{a}}$ & $2460^{\mathrm{ab}}$ & $2213^{\mathrm{ab}}$ & $1283.3^{\mathrm{b}}$ & $151.6^{\mathrm{c}}$ & $180.0^{c}$ & $113.3^{c}$ & $110.0^{c}$ & $90.0^{c}$ & 1298 & 0.001 \\
\hline Total return & $2114.3^{\mathrm{a}}$ & $2407.6^{\mathrm{a}}$ & $1531^{\mathrm{ab}}$ & $1284^{\mathrm{b}}$ & $354.3^{\mathrm{c}}$ & $1.6^{\mathrm{d}}$ & $30^{\mathrm{d}}$ & $-36.7^{\mathrm{d}}$ & $-40^{\mathrm{d}}$ & $-60^{\mathrm{d}}$ & 758.6 & 0.001 \\
\hline Net return & $830.5^{\mathrm{a}}$ & $1119.6^{\mathrm{a}}$ & $290.8^{\mathrm{b}}$ & $33^{\mathrm{c}}$ & $-820.2^{\mathrm{d}}$ & $-173^{d}$ & $-159^{d}$ & $-215^{\mathrm{c}}$ & $-221^{\mathrm{c}}$ & $-231.9^{c}$ & 45.4 & 0.003 \\
\hline
\end{tabular}

$\mathrm{T} 1=0 \%$ least-cost diet; $\mathrm{T} 2=25 \%$ least-cost diet; $\mathrm{T} 3=50 \%$ least cost diet; $\mathrm{T} 4=75 \%$ least cost diet and $\mathrm{T} 5=100 \%$ least cost diet; Similar letters are indicated no significant difference 


\section{Discussion}

\subsection{Composition of homemade ration}

In the current study, the fiber content is significantly $(\mathrm{P}<0.0001)$ higher than the report [12] due to different feed ingredients used for diet formulation. The chemical composition of the ingredients is depending on the maturity level, harvesting season, soil type and part of the ingredients to be used [13, 14]. In the current study, crude protein and energy content of least-cost ration is the lower amount [15]. However, crude protein and energy of the current study had similar observations with the effect of the exogenous enzyme with diet on broiler performance study $[16,17]$.

\subsection{Feed consumption}

The fibrous and bulky nature of the least-cost ration may be attributed to decrease feed intake to which coupled with the low nutrient (energy) content containing $[18,19]$. This seems to disagree with the report of [20] that feed consumption and the quantity of feed required per $\mathrm{kg}$ of gain in pigs increased with an increase in the dietary fiber. The current finding of daily feed intake contradicts earlier reports [21] but agrees with the total feed intake of the chicken. The total feed intake of the present study was similar to the report [22]. High dietary fiber is recognized to limit the amount of energy available to chicks and equally contributes to excessive nutrient excretion [23]. The MDFC of the current study was lower than [24] report. This is due to used different breed, altitude, and feed ingredients for the experiments.

\subsection{Feed conversion ratio}

A feed conversion ratio of chicken is the rate measuring of efficiency with which the bodies of the birds convert the feed into the desired output. The current finding was agreed with earlier reports [21] feed conversion ratio of the chicken. The present study of feed conversion ratio was also a similar observation with the report $[24,22,15]$.

\subsection{Growth performance}

The present finding of MIBW and MDBWG agrees with earlier reports [21, 25] while contradicts the finding of MFBW of Bovan Brawn chicken performance under backyard management system. The depression in growth performance of the groups fed on the treatment rations in which 75 and $100 \%$ of the commercial starters ration was substituted by homemade ration could be attributed to high fiber content and low nutritive value of the homemade ration [26-28]. The MWBWG of Sasso breed had higher but Indigenous had lower observation [29] result obtained from Botswana chicken by providing commercial diet for 18 weeks. The growth performance of chicks progressively increased, when the week increases in all treatments and breed [22], which was true in the present study. However, MFBW was lower than the report of [12] study on broiler growth performance evaluation by providing Toasted Bambara nut. An MFBW and MDBWG of Indigenous breed under intensive production system was lower than the current study [24].

\subsection{Economic feasibility of least-cost ration}

Reduction in feed cost per kg weight gain of chicks fed commercial ration had similar to be reported $[30,19]$. The observed reduction in feed cost per kg weight gain of chicks that consumed the commercial ration may probably be due to an 
increase in ADFI, improved feed efficiency, and utilization and improved ADWG of the chicks.

\section{Conclusions}

It is evident from the results obtained in this study that the least cost diet can be included in the commercial diet of Sasso starter diets at a 50\% level without adverse effects on chick's growth performance and to enhance cost reduction of feed per kg weight gain.

\section{Author Contributions:}

Conceptualization: Lemma Gulilat, Firew Tegegne.

Data curtatoin: Lemma Gulilat.

Formal analysis: Lemma Gulilat.

Investigation: Lemma Gulilat.

Methodology: Lemma Gulilat, Firew Tegegne, Solomon Demoke.

Project administration: Lemma Gulilat, Firew Tegegne, Solomon Demoke.

Visualization: Lemma Gulilat, Solomon Demeke.

Writing - original draft: Lemma Gulilat.

Writing - review \& editing: Lemma Gulilat, Firew Tegegne, Solomon Demoke.

Acknowledgments: I would like to express my heart full acknowledge for my supervisors' doctor Firew Tegegne and Professor Solomon Demeke to coach me and make a direction to complete my research successfully. I thank you, also the Ministry of Science and Higher Education (MOSHE) and Debre Tabor University to offered funds for my research.

Conflicts of Interest: the authors are declare there is not conflicts of interests

\section{References}

1. Alemu, D., T. Degefe, S. Ferede, S. Nzietcheung and D. Roy. Overview and background paper on Ethiopia's poultry sector: Relevance for HPAI research in Ethiopia. International Food Policy Research Institute (IFPRI), International Livestock Research Institute (ILRI), Royal Veterinary College (RVC), Washington, DC., USA; 2009. P.709-715.

2. Aklilu H. A \& C. J. M. Almekinders \& H. M. J. Udo \& A. J. Van der Zijpp. Village poultry consumption and marketing in relation to gender, religious festivals and market access. Trop Anim Health Prod. 2007; 39:165-177.

3. Tadelle Dessie, and Brian Ogle. Village poultry production systems in the Central Highlands of Ethiopia.Tropical Animal Health and Production. 2001; 33: 521-537.

4. Melkamu Bezabih and Wube Atalel. Constraints and Opportunities of Village Chicken Production in Debsan TiKara Keble at Gondar Zuria Woreda, North Gondar, Ethiopia. International Journal of Scientific and Research Publications. 2013; 3 (9).

5. A.K. Youssao, I. T. Alkoiret, M. Dahouda, M. N. Assogba, N-D. Idrissou, B. B. Kayang, V. Yapi-Gnaoré, H. M. Assogba, A. S. Houinsou, S. G. Ahounou, U. P. Tougan, X. Rognon and M. Tixier-Boichard. Comparison of growth performance, carcass characteristics and meat quality of Benin indigenous chickens and Label Rouge (T55×SA51). African Journal of Biotechnology. 2012; 11:15569-15579.

6. Yami Alemu and Dessie Taddele. The status of poultry research and development in Ethiopia. Proceedings of the 5th National Conference of Ethiopian Society of Animal Production (ESAP), May 15-17, 1997 Addis Ababa, Ethiopia; 1997.p.40-60. 
7. AOAC. Methods of Analysis of the Association of Official Analytical Chemists. 14th Ed, Association of Official Analytical Chemists, Washington, DC; 1990

8. Smail Abafi, Haydar Özpinar, H. Can kutay, Recep kahraman. Determination of the Metabolizable Energy (ME) and Net Energy Lactation (NEL) Contents of Some Feeds in the Marmara Region by In vitro Gas Technique. Turk J Vet Anim Sci. 2005; 29:751-757.

9. Dragan Palić , Djordje Okanović, Djordje Psodorov, Natalija Džinić, Slobodan Lilić, Vladislav Zekić and Dragan Milić. Prediction of metabolisable energy of poultry feeds by estimating in vitro organic matter digestibility. African Journal of Biotechnology. 2007; 11:7313-7317.

10. Upton M (1979). Farm Management in Africa, the Principal of Production and Planning, Oxford University Press, p. 380.

11. SAS. Statistical analysis Software version 9.2, Cary, NC: SAS Institute Inc. USA; 2008.

12. Oyeagu, C. E., Ani, A. O., Egbu, C. F., Akpolu, E. S., Iwuchukwu, J. C. and Omumuabuike, J. N.. Performance of broiler finisher birds fed toasted bambara nut (vigna subterranean offal with supplementary enzyme. Asian Journal of Science and Technology. 2015; 6:934-939.

13. McDowell, L.R., Conrad, J.H., Ellis, G.L. and Loosli, L.K. Minerals for grazing ruminants in tropical regions. Animal Science Department, University of Florida, Gainseville; 1983.

14. Khan, Z.I., Hussain, I.A., Ashraf, M., Valeem, E.E. and Javed, I. Evaluation of variation of soil and forage minerals in pasture in a semiarid region of Pakistan. Pakistan Journal of Botany. 2005; 37:921-931.

15. Tavares, Santos, Araújo, Costa, Loureiro, Lima, Lima, Kedson Raul de. Performance, growth and carcass characteristics of alternatives lineages of broiler chickens created with access to paddock. Rev. Prod. Animal. 2015; 16:420-429.

16. M.J Alam, M.A. Howlider, M.A Pramanik, and M.A Haque. Effect of exogenous enzyme in diet on broiler performance. International journal of poultry science. $2003 ; 2: 168-173$.

17. Y. K. Choo, H. J. Kwon, S. T. Oh, J. S. Um, B. G. Kim, C. W. Kang, S. K. Lee, B.

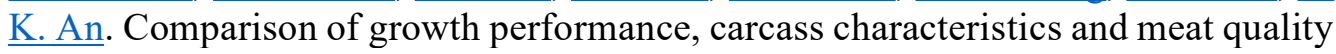
of Korean local chickens and silky fowl, Asian-Australasian journal of animal sciences (AJAS) 2014; 27(3): 398-405.

18. Apata, D.F. and Ojo, V. Efficacy of the Trichodema viride enzyme complex in broiler starters fed cowpea testa based diets proc. $25^{\text {th }}$ Ann. Conf. Nig. Soc. For Anim. Prod. (NSAP), March $19^{\text {th }}-23^{\text {rd }}, 2000$. Michael Okpara Univ. Agric. Umudike, Nigeria; 2000. p.132-134.

19. Ajaja K., Agbede J.O. and Aletor V.A. Influence of Roxazyme G supplementation on utilization of wheat offal or rice bran by broilers. Proc. Univ. Tech, Minna, Nigeria; 2003. P.32-34.

20. Pond WG, Lowrey RS and Manner JH. Effects of crude fiber level on ration digestibility and performance in growing finishing swine. J. Anim. Sci. 1974; 21:692-699.

21. G.S. Ojewola, F.C. Okoye and I. Agbakuru. Replacement Value of Cashewnut Meal for Soyabean Meal in Finishing Broiler Chickens. International Journal of Poultry Science. 2004; 3:513-516. 
22. V. Thanaseelaan, K.Viswanathan, K.Venukopalan, R. Prabakaran and M. Chellapandian. Effect of Feeding Rapeseed Meal in Meat Type Chicken. J. Veterinary \& Animal Sciences. 2008; 4:157-161.

23. Kung $\mathrm{P}$ and Grueling HT. Enzyme supplementation of a poultry diet containing rye and wheat. Br. J. Nutr. 2000; 62:139-149.

24. Solomon Demeke. Growth performance and survival of local and white leghorn chicken under intensive management system. Ethiop. J. Sci. 2004; 27:161-164.

25. Tomas Melkamu, Niraj Kumar, Berihu Gebrekidan, Etsay Kebede and Tsegay Tkue. Performance of Bovans Brown chickens under intensive and backyard management system in Mekelle, Ethiopia, Ethiopian. Journal of Veterinary Science and Animal Production. 2017; 1: 73-80.

26. Doku, J.A. and Karikari, O.O. Tropical Grasses. Legume Bulletin. 1981; 31:20-27.

27. Apata, D.F. and Qloghobo, A.D. Biochemical evaluation of some Nigerian legume seeds. Food Chem. 1994; 49:33-38.

28. Ensminger, M.E, Oldfied, J.E. and Heinemann, W.N. Feeds and Nutrition. The Ensminger publishing Coy; Clovis Califomia, USA; 1996.p. 324-366.

29. Malebogo Virginia Radikara, John Cassius Moreki, Molebeledi Horatius Dambe Mareko and Patrick Monametsi Kgwatalala. Effect of feeding commercial broiler diets on growth performance of Tswana and Orpington chickens reared up to 18 weeks of age under intensive system. Int. J. Poult. Sci. 2016; 15: 407-413.

30. Mikulshi D, Jankoweki J, El-Soud SBA, Farugh A and Abou-Zeid AE. Effect of feeding enzyme supplemented triticale-barley diets on broiler chicken. Egypt Poult. Sci. J. 1998; 19:607-618. 